Фармацевтична технологія, біофармація, гомеопатія Pharmaceutical technology, biopharmacy, homeopathy

Рекомендована д. фрармац. наук, профр. Т. А. Грошовим УДК 615.453.6:[577.112.387+[615.31:547.792]].012

DOI 0.11603/2312-0967.2017.4.8344

\title{
ВИБІР ДОПОМІЖНИХ РЕЧОВИН ДЛЯ ОТРИМАННЯ ТАБЛЕТОК L-ТРИПТОФАНУ З ТІОТРИАЗОЛІНОМ МЕТОДОМ ВОЛОГОЇ ГРАНУЛЯЦІї
}

\author{
() Л. І. Кучеренко ${ }^{1,2}$, І. А. Мазур ${ }^{1,2}$, С. О. Борсук \\ НВТ «Фарматрон», Запоріжжя \\ Запорізький державний медичний університет² \\ farm_chem@bigmir.net
}

\begin{abstract}
Мета роботи. Створення нового таблеткового лікарського засобу нейропсихотропної дії на основі L-триптосрану та тіотриазоліну. Підбір оптимальних допоміжних речовин (ДР), вивчення їх впливу на стійкість таблеток до роздавлювання, стираність, розпадання, зовнішній вигляд поверхні таблеток L-триптофану та тіотриазоліну після 6-ти місяців зберігання.

Матеріали і методи. Діючі речовини - L-триптофран та тіотриазолін у співвідношенні 4:1, ДР (наповнювачі, розпушувачі, зв'язуючі розчини, солюбілізатори). Таблетки пресували методом вологої грануляції. Вплив ДР на таблетки, до складу яких входять L-триптофран та тіотриазолін, вивчали за такими показниками: стійкість таблеток до роздавлювання, стираність, розпадання, зовнішній вигляд поверхні таблеток після 6-ти місяців зберігання.

Результати й обговорення. За результатами дисперсійного аналізу було встановлено, що на стійкість до роздавлювання серед зв'язуючих розчинів позитивний вплив має 5 \% розчин ГПМЦ; серед розпушувачів - натрій кроскармелоза; серед наповнювачів - суміш МКЦ 101 + крохмаль картопляний + лактоза моногідрат. Найменший вплив на стійкість до роздавлювання таблеток L-триптофану з тіотриазоліном чинить додавання солюбілізаторів. На стираність таблеток L-триптофрану 3 тіотриазоліном серед солюбілізаторів лідером $€$ аеросил; серед розпушувачів - поліплаздон ХЛ 10.

При дослідженні часу розпадання таблеток найбільш значущою є суміш МКЦ 101+ крохмаль картопляний + кальцій дигідрофоссрат безводний.

На зовнішній вигляд поверхні таблеток після шести місяців зберігання лідерами є натрій крохмальгліколят та суміш МКЦ 101 + крохмаль картопляний + магній карбонат основний.

Висновки. Вивчено вплив чотирьох груп ДР на стійкість таблеток L-триптофрану з тіотриазоліном до роздавлювання, стираність, час розпадання та зовнішній вигляд поверхні через 6 місяців зберігання. 3 метою отримання оптимального складу таблеток 3 L-триптофраном та тіотриазоліном відібрано такі ДР: суміш МКЦ $101+$ крохмаль картопляний + магній карбонат основний, натрій крохмальгліколят, 5 \% розчин ГПМЦ 5, аеросил, кальція стеарат. При використанні саме цих ДР були отримані таблетки L-триптофану з тіотриазоліном, які відповідають вимогам ДФУ щодо таблеток.
\end{abstract}

Ключові слова: L-триптофран; тіотриазолін; таблетки; допоміжні речовини; метод вологої грануляції; фрармакотехнологічні показники таблеток; математичне планування експерименту.

Повідомлення 2. Вплив допоміжних речовин на фармако-технологічні показники таблеток L-триптофану 3 тіотриазоліном, отриманих методом вологої грануляції.

Вступ. Початок теперішнього тисячоліття ознаменувався значним зменшенням тривалості та погіршенням якості життя. Це прямо пропорційно пов'язано зі збільшенням хворих із порушеннями центральної нервової системи, які виникли в результаті негативного впливу стресу [1]. У зв'язку з цим, створення нових, безпечних лікарських засобів на основі комбінацій анксіолітичного препарату з антиоксидантами, завдяки чому зменшиться велика кількість побічних ефектів та стане можливим розширення застосування нового препарату, є одним 3 головних завдань сучасної фрармації $[2,3]$.
3 огляду на це розроблено та створено комбінований лікарський засіб на основі триптофрану 3 тіотриазоліном в оптимальному співвідношенні 4:1. Саме при використанні комбінації таких діючих речовин та в цьому співвідношенні побічні ефекти триптофрану, а саме сухість в ротовій порожнині, сонливість, зниження апетиту, зменшилися, а спектр фрармакологічної дії розширився. Крім основної анксіолітичної дії триптофрану і антиоксидантної й протиішемічної дій тіотриазоліну, дана комбінація проявляє й додаткові стреспротекторний, а також ноотропний ефекти [4, 5].

Відомо, що однією з найпоширеніших і перспективних лікарських фрорм (ЛФ) є таблетки, які на даний час складають близько 65 \% загального обсягу анксіолітичних та 40 \% ноотропних готових лікарських форм. Дана ЛФ дає змогу застосовувати анксіолітич-

ISSN 2312-0967. Фармацевтичний часопис. 2017. № 4 
ні та ноотропні препарати пацієнтам поза межами лікувально-профрілактичного закладу [6].

Тому створення нового комбінованого нейропсихотропного засобу, до складу якого входить L-триптофан та тіотриазолін, є актуальною задачею сучасної медицини та фрармації.

Метою нашого дослідження $€$ створення нового таблеткового лікарського засобу нейропсихотропної дії, на основі L-триптофрану та тіотриазоліну, підбір оптимальних ДР, вивчення їх впливу на стійкість таблеток до роздавлювання, стираність таблеток, розпадання таблеток, зовнішній вигляд поверхні таблеток після 6-ти місяців зберігання.

Дані дослідження є продовженням комплексної наукової програми «Цілеспрямований пошук біологічно активних речовин в ряду азагетероциклів і створення оригінальних лікарських засобів та фріксованих комбінацій лікарських препаратів», яка реалізується співробітниками НВО «Фарматрон» і фрахівцями кафредри фрармацевтичної хімії Запорізького державного медичного університету.

Матеріали і методи. Як було зазначено в попередніх дослідженнях, при створенні таблеток L-триптофрану 3 тіотриазоліном враховували фрізикохімічні і технологічні властивості діючих речовин, їх співвідношення в складі таблеток, а також середню масу таблеток. Завдяки технологічним властивостям, для тіотриазоліну характерне пряме пресування, L-триптофан, у свою чергу, відноситься до дрібнодисперсних порошків, з яких можна отримати таблетки тільки з використанням методу вологої грануляції. Враховуючи все вище зазначене, було прийнято рішення використовувати метод вологої грануляції для отримання таблеток, до складу яких входять L-триптофран та тіотриазолін [6]. У дослідженні використані: L-триптофран (виробник: Sigma-Aldrich); тіотриазолін (виробник: Державне підприємство «Завод хімічних реактивів» Науково-технологічного комплексу «Інститут монокристалів» НАН України).

У процесі роботи було вивчено чотири групи допоміжних речовин, фрактори та їх рівні наведено в повідомленні 1 [6], а саме: комбіновані наповнювачі (фактор A) - $\mathrm{a}_{1}-$ МКЦ 101 + крохмаль картопляний+магнію карбонат основний, $\mathrm{a}_{2}$ - крохмаль картопляний + магнію карбонат основний+ кальцію дигідрофросфрат безводний, $\mathrm{a}_{3}$ - крохмаль картопляний + магнію карбонат основний + неусілін УФЛ, $\mathrm{a}_{4}$ - крохмаль картопляний + магнію карбонат основний + лактоза моногідрат; розпушувачі (фрактор В) $b_{1}$ - натрій кроскармелоза, $\mathrm{b}_{2}$ - поліплаздон ХЛ 10, $\mathrm{b}_{3}$ - натрій карбоксиметилкрохмаль, $\mathrm{b}_{4}$ - натрій крохмальгліколят; зв'язуючі розчини (фактор С) - c 1 - 3 к крохмальний клейстер, $\mathrm{c}_{2}-5 \%$ розчин гідрооксипропілметилцелюлози (ГПМЦ) 5, с -3 \% розчин метилцелюлози (МЦ) 15, $\mathrm{C}_{4}-7 \%$ розчин повідону 30 та солюбілізатори (фактор D) - $\mathrm{d}_{1}$ - без солюбілізатора, $\mathrm{d}_{2}-$ твін 80, $\mathrm{d}_{3}$ - натрій лаурилсульфрат, $\mathrm{d}_{4}-$ аеросил.
Фармацевтична технологія, біофармація, гомеопатія

Pharmaceutical technology, biopharmacy, homeopathy

У роботі використано сертифіковані ДР вітчизняного і закордонного виробництва.

Таблетки L-триптофрану з тіотриазоліном готували за класичною схемою методом вологої грануляції [7]. Таблетки отримували за допомогою лабораторного настільного таблеткового пресу $6000 \mathrm{~S}$ (виробник: Білорусь) 3 діаметром пуансонів 10 мм.

Для вивчення чотирьох якісних фракторів використовували греко-латинський квадрат 4x4 [8]. Матриця планування експерименту та результати дослідження таблеток L-триптофрану з тіотриазоліном наведені в таблиці 1. Досліди були реалізовані у двох повторностях, що дозволило зменшити помилку експерименту та отримати інформацію про можливу взаємодію між рівнями вивчених фракторів.

Було проаналізовано стійкість таблеток до роздавлювання ( $\mathrm{y}_{4}$ і у у '), згідно з ДФУ (ДФУ 2 Том п.2.9.8.).

Вивчали стираність таблеток L-триптофрану 3 тіотриазоліном за допомогою приладу PHARMA TEST AG Siemensstrasse 5 D-63512 Hainburg (Germany) $\left(y_{5}\right.$ і у у '), згідно з ДФУ (ДФУ 2 Том п.2.9.7.).

Розпадання таблеток проводили на приладі ERWEKA ZTx20 ( ( $_{6}$ і у $\left.{ }_{6}^{\prime}\right)$, згідно 3 ДФУ (ДФУ 2 Том п.2.9.1.) [9].

Зовнішній вигляд поверхні таблеток L-триптофрану 3 тіотриазоліном після шести місяців зберігання $\left(\mathrm{y}_{7} \mathrm{i}\right.$ $\left.\mathrm{y}_{7}{ }^{\prime}\right)$ оцінювали на якість поверхні та зміну кольору.

За результатами експериментальних досліджень проводили дисперсійний аналіз експериментальних даних та робили висновки про вплив вивчених фракторів на показники якості таблеток L-триптофрану 3 тіотриазоліном [8].

Результати й обговорення. В лабораторних умовах були виготовлені 16 серій таблеток L-триптофану 3 тіотриазоліном методом вологої грануляції. Матриця планування експерименту та результати дослідження таблеток, до складу яких входить L-триптофран та тіотриазолін, наведені в таблиці 1, де $\mathrm{y}_{4}$ і у , $_{4}-$ стійкість таблеток до роздавлювання першої і другої серії дослідів, Н; y $_{5}$ і у ' - стираність таблеток першої і другої серії дослідів, \%; у і у '- розпадання таблеток першої і другої серії дослідів, хв; $\mathrm{y}_{7}$ і $\mathrm{y}_{7}{ }^{\prime}-$ зовнішній вигляд поверхні таблеток після 6-ти місяців зберігання першої і другої серії дослідів, бали.

При дослідженні таблеток на основі L-триптосрану 3 тіотриазоліном на стійкість до роздавлювання на підставі дисперсійного аналізу експериментальних даних встановлено, що вивчені якісні фрактори можна розмістити в такій послідовності: C > B > A > D.

Після проведення дисперсійного аналізу експериментальних даних будували рисунки, на яких вказані середні значення вивченого показника.

Вплив природи зв'язуючого розчину на стійкість таблеток L-триптофрану та тіотриазоліну до роздавлювання зображено на рисунку 1.

З даних рисунка 1 видно, що найбільш стійкі до роздавлювання таблетки 3 L-триптофраном та тіотриазолі-

ISSN 2312-0967. Pharmaceutical review. 2017. № 4 
Фармацевтична технологія, біофармація, гомеопатія Pharmaceutical technology, biopharmacy, homeopathy

Таблиця 1. Чотирифакторний експеримент на основі 4x4 греко-латинського квадрату та результати дослідження таблеток L-триптофрану з тіотриазоліном

\begin{tabular}{|c|c|c|c|c|c|c|c|c|c|c|c|c|}
\hline $\begin{array}{c}\text { № } \\
\text { 3/ח }\end{array}$ & $\mathrm{A}$ & $\mathrm{B}$ & $\mathrm{C}$ & $\mathrm{D}$ & $\mathrm{y}_{4}$ & $\mathrm{y}_{4}^{\prime}$ & $\mathrm{y}_{5}$ & $\mathrm{y}_{5}^{\prime}$ & $\mathrm{y}_{6}$ & $\mathrm{y}_{6}^{\prime}$ & $\mathrm{y}_{7}$ & $\mathrm{y}_{7}^{\prime}$ \\
\hline 1 & $\mathrm{a}_{1}$ & $\mathrm{~b}_{1}$ & $\mathrm{c}_{1}$ & $\mathrm{~d}_{1}$ & 104,5 & 99,8 & 0,37 & 0,39 & 3,43 & 4,93 & 3 & 4 \\
\hline 2 & $\mathrm{a}_{1}$ & $\mathrm{~b}_{2}$ & $\mathrm{c}_{2}$ & $\mathrm{~d}_{4}$ & 114,9 & 117,4 & 0,06 & 0,11 & 22,02 & 24,10 & 5 & 5 \\
\hline 3 & $\mathrm{a}_{1}$ & $\mathrm{~b}_{3}$ & $\mathrm{c}_{3}$ & $\mathrm{~d}_{2}$ & 97,6 & 100,5 & 0,26 & 0,27 & 7,42 & 8,23 & 4 & 4 \\
\hline 4 & $\mathrm{a}_{1}$ & $\mathrm{~b}_{4}$ & $\mathrm{c}_{4}$ & $\mathrm{~d}_{3}$ & 119,3 & 124,4 & 0,28 & 0,29 & 39,92 & 40,65 & 5 & 4 \\
\hline 5 & $\mathrm{a}_{2}$ & $\mathrm{~b}_{1}$ & $\mathrm{c}_{2}$ & $\mathrm{~d}_{3}$ & 130,1 & 135,4 & 0,43 & 0,45 & 3,83 & 4,22 & 4 & 4 \\
\hline 6 & $\mathrm{a}_{2}$ & $\mathrm{~b}_{2}$ & $\mathrm{c}_{1}$ & $\mathrm{~d}_{2}$ & 68,9 & 67,2 & 0,41 & 0,39 & 3,88 & 4,22 & 4 & 4 \\
\hline 7 & $\mathrm{a}_{2}$ & $\mathrm{~b}_{3}$ & $\mathrm{c}_{4}$ & $\mathrm{~d}_{4}$ & 134,6 & 133,3 & 0,08 & 0,10 & 37,90 & 35,98 & 4 & 4 \\
\hline 8 & $\mathrm{a}_{2}$ & $\mathrm{~b}_{4}$ & $\mathrm{c}_{3}$ & $\mathrm{~d}_{1}$ & 118,6 & 124,3 & 0,17 & 0,16 & 6,68 & 6,97 & 5 & 5 \\
\hline 9 & $\mathrm{a}_{3}$ & $\mathrm{~b}_{1}$ & $\mathrm{c}_{3}$ & $\mathrm{~d}_{4}$ & 155,1 & 149,9 & 0,24 & 0,26 & 7,92 & 6,28 & 4 & 3 \\
\hline 10 & $\mathrm{a}_{3}$ & $\mathrm{~b}_{2}$ & $\mathrm{c}_{4}$ & $\mathrm{~d}_{1}$ & 147,8 & 149,2 & 0,17 & 0,17 & 120,22 & 116,93 & 4 & 3 \\
\hline 11 & $\mathrm{a}_{3}$ & $\mathrm{~b}_{3}$ & $\mathrm{c}_{1}$ & $\mathrm{~d}_{3}$ & 122,1 & 124,4 & 0,15 & 0,16 & 5,15 & 5,50 & 4 & 5 \\
\hline 12 & $\mathrm{a}_{3}$ & $\mathrm{~b}_{4}$ & $\mathrm{c}_{2}$ & $\mathrm{~d}_{2}$ & 150,7 & 148,2 & 0,24 & 0,26 & 28,35 & 25,67 & 3 & 4 \\
\hline 13 & $\mathrm{a}_{4}$ & $\mathrm{~b}_{1}$ & $\mathrm{c}_{4}$ & $\mathrm{~d}_{2}$ & 69,2 & 73,8 & 0,17 & 0,15 & 9,00 & 8,38 & 5 & 4 \\
\hline 14 & $\mathrm{a}_{4}$ & $\mathrm{~b}_{2}$ & $\mathrm{c}_{3}$ & $\mathrm{~d}_{3}$ & 171,0 & 169,2 & 0,02 & 0,07 & 9,42 & 9,00 & 4 & 3 \\
\hline 15 & $\mathrm{a}_{4}$ & $\mathrm{~b}_{3}$ & $\mathrm{c}_{2}$ & $\mathrm{~d}_{1}$ & 167,5 & 162,7 & 0,24 & 0,25 & 32,72 & 28,93 & 4 & 3 \\
\hline 16 & $\mathrm{a}_{4}$ & $\mathrm{~b}_{4}$ & $\mathrm{c}_{1}$ & $\mathrm{~d}_{4}$ & 192,4 & 194,5 & 0,21 & 0,23 & 9,25 & 7,45 & 5 & 5 \\
\hline
\end{tabular}

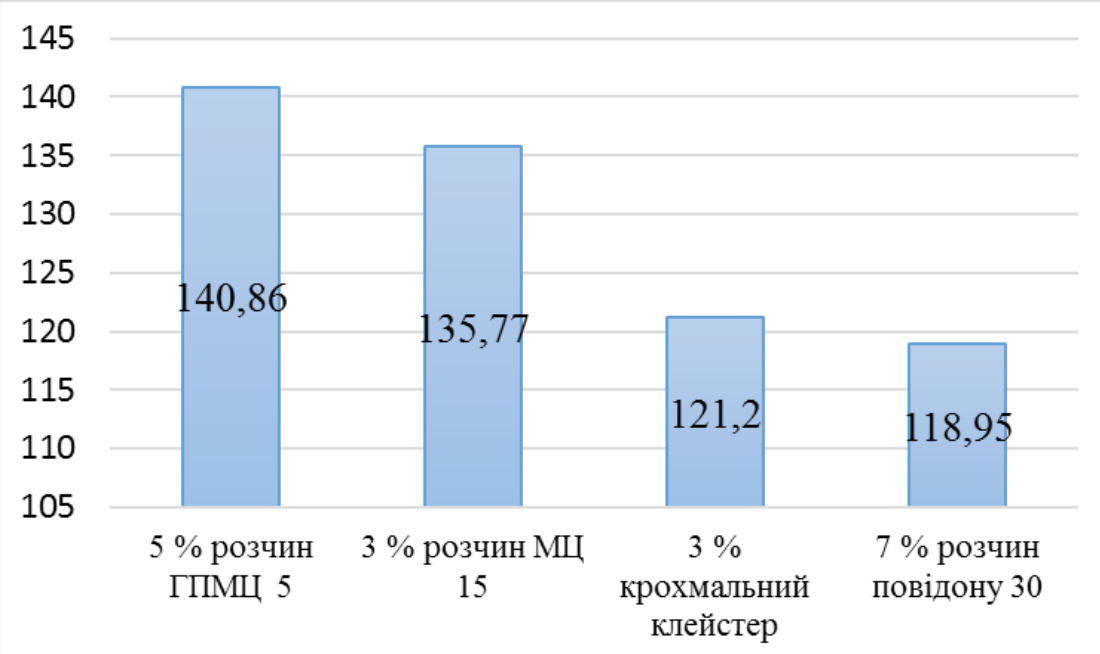

Рис. 1. Вплив природи зв'язуючого розчину на стійкість таблеток L-триптосрану з тіотриазоліном до роздавлювання.

ном отримано при використанні в якості зв'язуючого $5 \%$ розчин ГПМЦ $(140,86$ H), який має перевагу над 3 \% розчином МЦ 15(135,77 Н), крохмальним клейстером $(121,2$ H) і 7 \% розчином повідону $30(118,95$ H).

Подібним чином будували рисунки для інших вивчених якісних фракторів. Встановлено, що натрій крохмальгліколят $(146,5$ H) дозволяє отримати таблетки L-триптофрану з тіотриазоліном з найбільшою стійкістю до роздавлювання і має переваги над натрій карбоксиметилкрохмалем (130,3 Н), поліплаздоном ХЛ $10(125,7$ Н) та натрій кроскармелозою $(114,72$ H).

Найбільш стійкі до роздавлювання таблетки 3 L-триптофраном та тіотриазоліном отримували при використанні в якості наповнювача (срактор А) суміші МКЦ 101 + крохмаль картопляний + лактоза моногідрат $(150 \mathrm{H})$, яка має переваги над сумішами МКЦ 101 + крохмаль картопляний + неусілін УФЛ (143.4Н), МКЦ 101+ крохмаль картопляний + кальцій дигідрофросфат безводний $(114,0$ Н) і МКЦ 101 + крохмаль картопляний + магній карбонат основний $(109,8$ H).

Найменший вплив на стійкість до роздавлювання таблеток L-триптофрану з тіотриазоліном чинить природа солюбілізаторів (фрактор D). Серед них лідером $\epsilon$ аеросил $(149,0$ H), який має перевагу над натрій лаурилсульсратом (136,9 H), без солюбілізатора $(134,3$ H) і твіном $80(97,0$ H). Первинні результати та

ISSN 2312-0967. Фармацевтичний часопис. 2017. № 4 
значення середніх величин показали, що вдалося отримати таблетки L-триптофрану 3 тіотриазоліном достатньою стійкістю до роздавлювання.

Результати дисперсійного аналізу показали, що на стираність таблеток, на основі L-триптосрану та тіотриазоліну впливають всі чотири вивчені фрактори: D > B > A > C.

Вплив солюбілізаторів на стираність таблеток 3 L-триптосраном та тіотриазоліном зображено на рисунку 2.

Найменше значення стираності спостерігається в серіях таблеток, в яких було використано в якості солюбілізатора аеросил (0,16 \%), який має перевагу над іншими серіями таблеток 3 додаванням натрій лаурилсульфату (0,23 \%), без додавання солюбілізатора $(0,24 \%)$ та твіну $80(0,27 \%)$.

Розглянуто вплив розпушувачів (срактор В) на стираність таблеток, на основі L-триптофрану та тіотриазоліну. Найменша стираність таблеток L-триптофрану з тіотриазоліном отримано при використанні поліплаздону ХЛ 10 (0,17 \%). При використанні карбоксиметилкрохмалю (0,18 \%), натрій крохмальгліколяту (0,23\%) та натрій кроскармелози (0,31 \%) стираність таблеток була більшою.

На наступному етапі роботи досліджувався вплив наповнювачів на стираність таблеток, до складу яких входять L-триптофран та тіотриазолін.
Фармацевтична технологія, біофармація, гомеопатія Pharmaceutical technology, biopharmacy, homeopathy

Аналіз середніх значень показав, що вивчені ДР за впливом на стираність таблеток можна розмістити в такій послідовності: МКЦ 101 + крохмаль картопляний+лактоза моногідрат $(0,17$ \%) > МКЦ 101+ крохмаль картопляний +неусілін УФЛ $(0,21 \%)>$ МКЦ 101+крохмаль картопляний + магній карбонат основний $(0,25 \%)>$ МКЦ 101+крохмаль картопляний+кальцій дигідрофоссрат безводний (0,27\%). Найкраще себе проявила суміш МКЦ 101+крохмаль картопляний+лактоза моногідрат, тоді як суміш МКЦ 101+крохмаль картопляний+кальцій дигідрофросфат безводний показала найвищий відсоток стираності таблеток. Зазначимо, що отримані таблетки L-триптофану з тіотриазоліном в усіх серіях дослідів були стійкими до стирання і первинні результати не перевершували 0,50 \%.

Дисперсійний аналіз експериментальних даних показав, що вплив вивчених фракторів на час розпадання таблеток 3 L-триптофраном та тіотриазоліном можна зобразити таким рядом переваг: A > D > B > res при статистичній незначущості фрактора C.

Вплив наповнювачів на розпадання таблеток L-триптофану з тіотриазоліном зображено на рисунку 3.

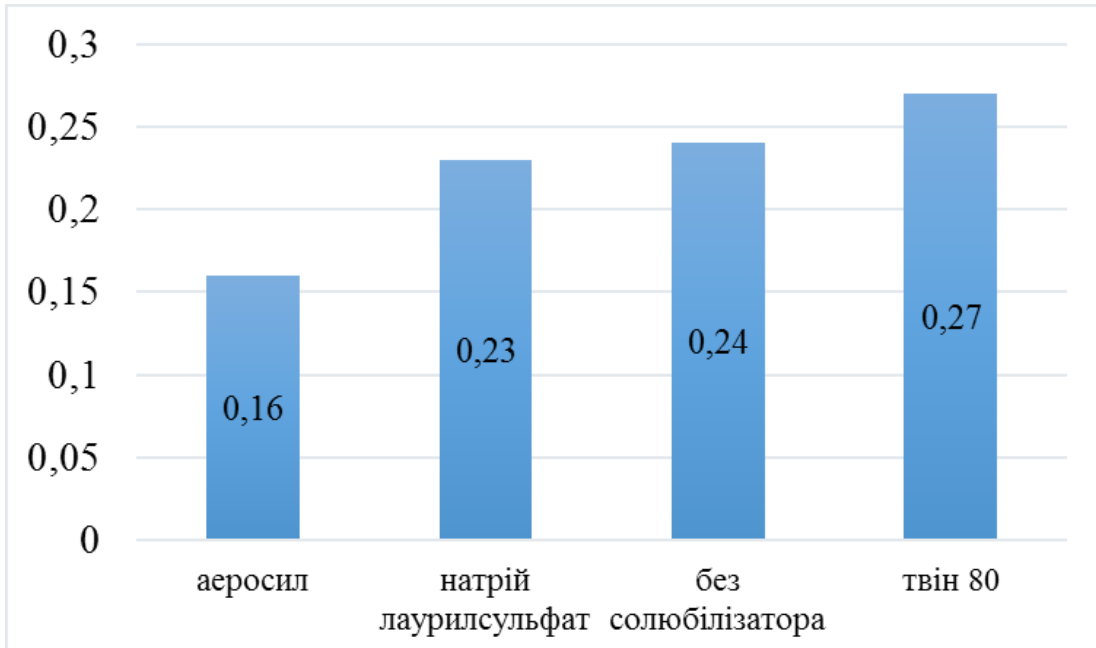

Рис. 2. Вплив солюбілізаторів на стираність таблеток з L-триптофраном та тіотриазоліном.

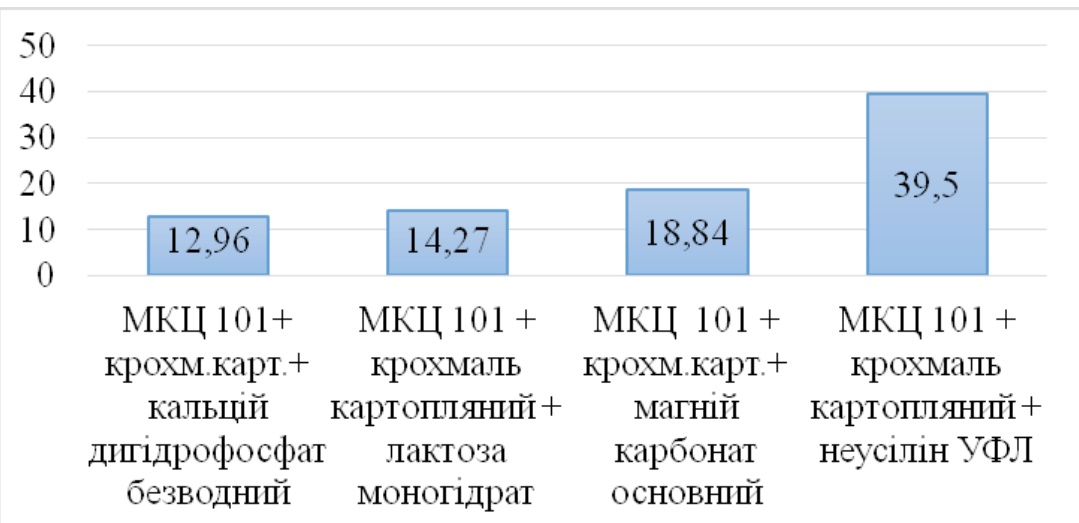

Рис. 3. Вплив наповнювачів на розпадання таблеток L-триптофрану з тіотриазоліном.

ISSN 2312-0967. Pharmaceutical review. 2017. № 4 
Фармацевтична технологія, біофармація, гомеопатія Pharmaceutical technology, biopharmacy, homeopathy

Порівняння середніх значень рівнів фрактора А показало, що найшвидше розпадалися таблетки, до складу яких входить L-триптофран з тіотриазоліном при використанні в якості наповнювача суміш МКЦ 101+крохмаль картопляний+кальцій дигідрофоосрат безводний (12,96 хв). Вказаний розпушувач має суттєву перевагу над іншою сумішшю ноповнювачів, яка складається 3 МКЦ 101+крохмаль картопляний+лактоза моногідрат (14,27 хв). Зауважимо, що при використанні в якості наповнювача МКЦ 101+крохмаль картопляний+магній карбонат основний $(18,84$ хв) та МКЦ 101+крохмаль картопляний + неусілін УФЛ (39,5 хв) середнє значення часу розпадання таблеток перевершувало вимоги ДФ України (більше 15 хв).

Серед вивчених солюбілізаторів найшвидше розпадалися таблетки L-триптофрану з тіотриазоліном, це забезпечує твін 80 (11,8 хв), який має перевагу над натрію лаурилсульсрат (14,7 хв), аеросилом $(18,8$ хв) і складом таблеток без солюбілізатора $(40,1 \times B)$.

У групі розпушуючих речовин за впливом на час розпадання таблеток L-триптофану з тіотриазоліном спостерігається суттєва перевага натрій кроскармелози (5,9 хв) над натрій карбоксиметилкрохмалем (20,2 хв), натрій крохмальгліколятом (20,6 хв) та поліплаздоном ХЛ10 (26,0 хв)

Таблетки на основі L-триптофану та тіотриазоліну оцінювали за зміною зовнішнього вигляду після 6-ти місяців зберігання. Встановлено, що на цей показник впливають наступні фрактори: B > A > res при статистичній незначущості фракторів C і D. На відміну від результату оцінки поверхні таблеток L-триптофрану 3 тіотриазоліном після виготовлення таблеток, коли статистично значущим виявився фрактор С (природа зв'язуючих розчинів).

Вплив розпушувачів на зовнішній вигляд таблеток L-триптофрану з тіотриазоліном після 6-ти місяців зберігання зображено на рисунку 4.

Ефективність розпушувачів за впливом на якість поверхні таблеток, до складу яких входить L-триптофран з тіотриазоліном, після 6-ти місяців зберігання можна зобразити в такій послідовності: натрій крохмальгліколят (4,5 бала) > натрій карбокси- метилкрохмаль (4,25 бала) > поліплаздон ХЛ 10 (4,25 бала) > натрій кроскармелоза (3,87 бала). Зауважимо, що при використанні натрій крохмальгліколяту зовнішній вигляд досліджуваних таблеток майже не змінився, тоді як при використанні натрій карбоксиметилкрохмалю, поліплаздону ХЛ 10 якість поверхні таблеток після 6-ти місячного зберігання зменшилась на 0,25 бала.

Найкращу якість поверхні таблеток L-триптофрану 3 тіотриазоліном після 6-ти місяців зберігання забезпечує суміш МКЦ 101+крохмаль картопляний + магній карбонат основний (4,25 бала) та МКЦ 101+крохмаль картопляний+ кальцій дигідрофросфат безводний (4,25 бала), яким дещо поступається суміш МКЦ 101+крохмаль картопляний + лактоза моногідрат (4,12 бала) і суттєво поступається МКЦ $101+$ крохмаль картопляний + неусілін УФЛ (3,75 бала).

Проведені дослідження дозволили вивчити вплив основних груп допоміжних речовин, які найчастіше використовують при створенні таблеток методом вологої грануляції. За дослідженими фрармако-технологічними показниками отримані позитивні результати за відгуками щодо більшості із вивчених ДР. Рішення щодо кращих ДР для отримання таблеток L-триптофрану 3 тіотриазоліном приймали на підставі даних, які відображеня в Повідомленні 1 [6] та в цій роботі.

Серед вивчених наповнювачів найкращим раціонально вважати суміш МКЦ 101+ крохмаль картопляний+магній карбонат основний, за допомогою якої забезпечується найкраща однорідність та гомогенність таблеткової маси таблеток L-триптофрану 3 тіотриазоліном $\left(\mathrm{y}_{1}\right)$, зовнішній вигляд $\left(\mathrm{y}_{3}\right)$, стираність $\left(\mathrm{y}_{5}\right)$ та зовнішній вигляд досліджуваних таблеток після 6 місяців зберігання $\left(\mathrm{y}_{7}\right)$.

Серед вивчених розпушувачів найкращі фрармакотехнологічні показники таблеток 3 L-триптофраном та тіотриазоліном забезпечувались за допомогою натрій крохмальгліколяту. За допомогою вказаної ДР отримано таблетки 3 найкращими процесом пресування $\left(\mathrm{y}_{2}\right)$, зовнішнім виглядом $\left(\mathrm{y}_{3}\right)$, міцністю $\left(\mathrm{y}_{4}\right)$ та зовнішнім виглядом після 6 місяців зберігання $\left(\mathrm{y}_{7}\right)$.

Серед вивчених зв'язуючих розчинів немає вираженого «лідера» за всіма фрармако-технологічними

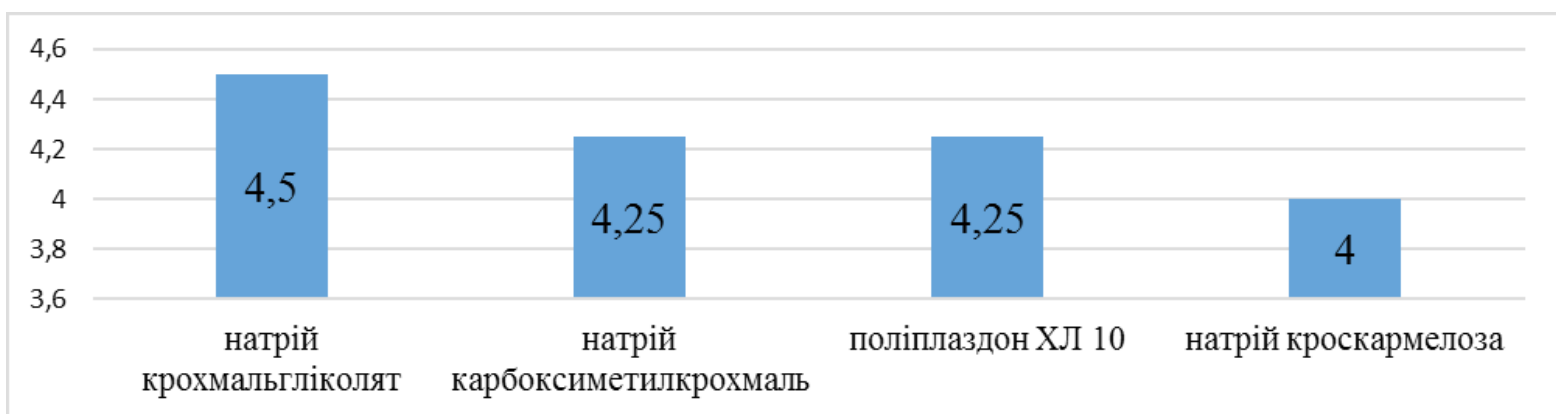

Рис. 4. Вплив природи розпушувачів на зовнішній вигляд таблеток, до складу яких входить L-триптофану 3 тіотриазоліном після 6-ти місяців зберігання.

ISSN 2312-0967. Фармацевтичний часопис. 2017. № 4 
показниками таблеток на основі L-триптофрану 3 тіотриазоліном. Встановлено, що найкраща однорідність та гомогенна маса таблеток $\left(\mathrm{y}_{1}\right)$, процес пресування $\left(\mathrm{y}_{2}\right)$ та міцність таблеток $\left(\mathrm{y}_{4}\right)$ забезпечується використанням $5 \%$ розчину ГПМЦ 5. Заслуговує також на увагу 3 \% крохмальний клейстер, за допомогою якого найкраще забезпечуються такі фрармакотехнологічні параметри: зовнішній вигляд таблеток $\left(\mathrm{y}_{3}\right)$, процес розпадання $\left(\mathrm{y}_{6}\right)$ та зовнішній вигляд після 6 місяців зберігання $\left(\mathrm{y}_{7}\right)$.

Лідером серед солюбілізаторів можна вважати аеросил, за допомогою якого найкраще забезпечується однорідність середньої маси таблеток із L-триптофраном та тіотриазоліном $\left(\mathrm{y}_{1}\right)$, міцність $\left(\mathrm{y}_{4}\right)$ та зовнішній вигляд таблеток після 6 місяців зберігання $\left(\mathrm{y}_{7}\right)$. Серед даних ДР варто відмітити твін 80, за допомогою якого найкращий показник досягається за стираністю $\left(\mathrm{y}_{5}\right)$ та розпаданням таблеток L-триптофрану 3 тіотриазоліном $\left(\mathrm{y}_{6}\right)$. Серед змащувальних речовин відібраний кальція стеарат.

У результаті проведених досліджень були відібрані раціональні ДР для створення таблеток L-триптофрану з тіотриазоліном. Для цього свій вибір зупинили на таких ДР: суміш МКЦ 101+крохмаль
Фармацевтична технологія, біофармація, гомеопатія

Pharmaceutical technology, biopharmacy, homeopathy

картопляний+магній карбонат основний, натрій крохмальгліколят, 5 \% розчин ГПМЦ 5, аеросил, кальцію стеарат. Дані допоміжні речовини забезпечують відповідність отриманих таблеток всім фрармако-технологіним вимогам, вказаним в ДФУ.

Висновки. Були проведені дослідження з вибору раціональних допоміжних речовин методом вологої грануляції. Досліджено 16 допоміжних речовин (наповнювачі, розпушувачі, зв'язуючі розчини, солюбілізатори). Відібрано оптимальні ДР, які забезпечують всі фрармако-технологічні вимоги, які висуваються до таблеткової лікарської форми ДФУ.

Для створення нового комбінованого лікарського засобу, що містить L-триптофран та тіотриазолін методом вологої грануляції, 316 ДР було відібрано 5 оптимальних (суміш МКЦ 101 + крохмаль картопляний + магній карбонат основний, натрій крохмальгліколят, 5 \% розчин ГПМЦ 5, аеросил, кальцію стеарат).

Беручи до уваги результатів якісного і кількісного співвідношення обраних допоміжних речовин, розроблено оптимальний склад та технологію отримання таблеток 3 L-триптофраном та тіотриазоліном методом вологої грануляції.

\title{
ВЫБОР ВСПОМОГАТЕЛЬНЫХ ВЕЩЕСТВ ДЛЯ ПОЛУЧЕНИЯ ТАБЛЕТОК L-TРИПТОФАНА С ТИОТРИАЗОЛИНОМ МЕТОДОМ ВЛАЖНОЙ ГРАНУЛЯЦИИ
}

\author{
Л. И. Кучеренко ${ }^{1,2}$, И. А. Мазур ${ }^{1,2}$, С. А. Борсук ${ }^{2}$ \\ НПО «Фарматрон»1, Запорожье \\ Запорожский государственный медицинский университет² \\ farm_chem@bigmir.net
}

Цель работы. Создание нового таблеточного лекарственного средства нейропсихотропного действия на основе L-триптофрана и тиотриазолина. Подбор оптимальных вспомогательных веществ (BB), изучение их влияния на устойчивость таблеток к раздавливанию, истираемость, распадание, внешний вид поверхности таблеток L-триптофана и тиотриазолина после 6 месяцев хранения.

Материалы и методы. Действующие вещества - L-триптофран и тиотриазолин в соотношении 4:1, BB (наполнители, разрыхлители, связующие растворы, солюбилизаторы). Таблетки прессовали методом влажной грануляции. Влияние BB на таблетки, в состав которых входят L-триптофран и тиотриазолин, изучали по следующим показателям: устойчивость таблеток к раздавливанию, истираемость, распадаемость, внешний вид поверхности таблеток после 6 месяцев хранения.

Результаты и обсуждение. По результатам дисперсионного анализа было установлено, что на устойчивость к раздавливанию среди связующих растворов положительное влияние имеет $5 \%$ раствор ГПМЦ; среди разрыхлителей - натрий кроскармеллоза; среди наполнителей - смесь МКЦ 101 + крахмал картофельный + лактоза. Наименьшее влияние на устойчивость к раздавливанию таблеток L-триптофана с тиотриазолином оказывает добавление солюбилизаторов.

На истираемость таблеток L-триптофрана с тиотриазолином среди солюбилизаторов лидером является аэросил; среди разрыхлителей - полиплаздон ХЛ 10.

При исследовании времени распадаемости таблеток наиболее значимой является смесь МКЦ 101+ крахмал картофельный + кальций дигидрофросфат безводный.

На внешний вид поверхности таблеток после шести месяцев хранения лидерами являются натрий крахмалгликолят и смесь МКЦ 101 + крахмал картофельный + магний карбонат основной.

Выводы. Изучено влияние четырех групп BB на устойчивость таблеток L-триптофрана с тиотриазолином к раздавливанию, истираемость, распадаемость и внешний вид поверхности через 6 месяцев хранения. С целью получения оптимального состава таблеток C L-триптофаном и тиотриазолином отобраны такие BB: cмесь MKЦ 101

ISSN 2312-0967. Pharmaceutical review. 2017. № 4 
Фармацевтична технологія, біофармація, гомеопатія

Pharmaceutical technology, biopharmacy, homeopathy

+ крахмал картофрельный + магний карбонат основной, натрия крахмалгликолят, 5 \% раствор ГПМЦ 5, аэросил, кальция стеарат. При использовании именно этих BB были получены таблетки L-триптофрана с тиотриазолином, которые соответствуют требованиям ГФУ по таблеткам.

Ключевые слова: L-триптофран; тиотриазолин; таблетки; вспомогательные вещества; метод влажной грануляции; фрармако-технологические показатели таблеток; математическое планирование эксперимента.

\title{
SELECTION OF EXCIPIENTS FOR L-TRIPTOPHANE TABLETS WITH THIOTRIAZOLINE BY WET GRANULATION
}

\author{
L. I. Kucherenko, ${ }^{1,2}$ I. A. Mazur ${ }^{1,2}$, S. A. Borsuk ${ }^{2}$ \\ $R P A$ «Farmatron» ${ }^{1}$, \\ Zaporizhzhia State Medical University ${ }^{2}$ \\ farm_chem@bigmir.net
}

The aim of the work. Creation of a new tablet with neuro psychotropic effect based on L-tryptophan and thiotriazoline. Selection of optimal excipients, study of their effect on hardness of tablets, friability, disintegration, the external appearance of coatings of L-tryptophan and thiotriazoline tablets after 6 months of storage.

Materials and Methods. The active substances: L-tryptophan and thiotriazoline in a ratio of 4:1, (excipients - fillers, disintegrants, binders, solubilizers). The tablets were compressed by wet granulation method. The effect of excipients on tablets containing L-tryptophan and thiotriazoline was studied according to the following parameters: hardness, friability, decomposition, external appearance of coatings after 6 months of storage.

Results and Discussion. The results of analysis of variance showed that $5 \%$ solution of hydroxypropymethylcellulose have the best effect on the hardness among binders; sodium croscarmellose have the best effect among disintegrants; mixture of microcrystalline cellulose 101+Solani amylum+ Lactose monohydrate - among fillers. Solubilizers have minimum effect on hardness of L-tryptophan with thiotriazoline.

Aërosilum have the maximum effect on friability of L-tryptophan with thiotriazoline among solubilizers; among disintegrants - Polyplasdone XL 10;

The mixture of MCC 101+Solani amylum+calcium dihydrogen phosphate anhydrous have the best effect on the time of disintegration time of tablets.

Sodium starch glycolate and MCC 101+Solani amylum+ basic magnesium carbonate have the best effect on the external appearance of coatings of tablets after six months of storage.

Conclusions. The effect of the four groups of excipients on the hardness, friability, disintegration time, the external appearance of coatings after six months of storage of L-tryptophan with thiotriazoline tablets was studied. The following excipients were selected in order to obtain optimal composition tablets with L-tryptophan and thiotriazoline: mixture of MCC 101 + Solani amylum + basic magnesium carbonate, sodium starch glycolate, $5 \%$ solution of HPMC 5, Aërosilum, calcium stearate. L -tryptophan with thiotriazoline tablets were obtained in using of these excipients which meet the requirements of the SPU regarding tablets.

Key words: L-tryptophan; thiotriazoline; tablets; excipients; wet granulation method; pharmacological and technological parameters of tablets; mathematical planning of the experiment.

\section{Список літератури}

1. Gbiadoni L. Mental stress induces transient endothelial dysfunction in humans / L. Gbiadoni, A. Donald, M. Cropley // Circulation. - 2000. - No. 102. - P. 2473-2478.

2. Разработка лекарственных средств на основе фиксированных комбинаций с антиоксидантами перспективное направление современной срармакологии / И. А. Мазур, И. С. Чекман, И. Ф. Беленичев [и др.] // Фармакологія та лікарська токсикологія. - 2011. - № 5. - C. 199-200.

3. Демчук М. Б. Досвід створення комбінованих препаратів на основі тіотриазоліну / М. Б. Демчук, О. В. Тригубчак, М. М. Васенда // Фармація України. Погляд у майбутнє : матеріали VII Нац. з"їзду фармацевтів України, 15-17 вер. 2010 р., Харків. Харків, 2010. - Т. 1. - С. 469.

4. Пат. на винахід № а201604961, Україна. Комбінований лікарський засіб анксіолітичної, стрес-протективної, ноотропної, антиоксидантної дії / Кучеренко Л. І., Борсук С. О., Бєленічев І. Ф.; - заявл. 04.05.2016; опубл. 24.06.16, Бюл. № 12.

5. Изучение фрармакологических свойств нового комбинированного лекарственного средства триптофрана с тиотриазолином (Сообщение 1) / Л. И. Кучеренко, И. Ф. Беленичев, И. А. Мазур [и др.] // Рецепт. - 2016. - Том 19, № 6. - С. 697 - 703.

6. Вибір допоміжних речовин для отримання таблеток L-триптосрану 3 тіотриазоліном методом вологої грануляції (Повідомленя 1) / Л. І. Кучеренко, І. А. Мазур, С. О. Борсук, [та ін.] // Фармацевтичний часопис. - № 3. - 2017. - C. 31-38.

ISSN 2312-0967. Фармацевтичний часопис. 2017. № 4 
7. Вибір раціональних допоміжних речовин для створення таблеток «Ангіолін» методом вологої грануляції / О. С. Бідненко, Л. І. Кучеренко, І. А. Мазур [та ін.] // Фармацевт. часоп. - 2016. - № 2. - С. 16-21.

8. Математичне планування експерименту при проведенні наукових досліджень в фрармації / [Грошо-
Фармацевтична технологія, біофармація, гомеопатія Pharmaceutical technology, biopharmacy, homeopathy вий Т. А., Марценюк В. П., Кучеренко Л. І. та ін.]. Тернопіль : Укрмедкнига, 2008. - 367 с.

9. Державна Фармакопея України : в 3 т. / Держ. п-во «Укр. науковий фрармакопейний центр якості лікарських засобів». - 2-е вид. - Х. : Держ. п-во «Укр. наук. фрармакопейний центр якості лікарських засобів», 2014. - Т. 1. - 1126 с.

\section{References}

1. Gbiadoni L, Donald, Cropley M. Mental stress induces transient endothelial dysfunction in humans. Circulation. 2000;102: 2473-8.

2. Mazur IA, Chekman IS, Belenichev IF. [Development of drugs based on fixed combinations with antioxidants is a promising area of modern pharmacology]. Farmakol and likar. toksikol. 2011;5: 199-200. Russian.

3. Demchuk MB, Tryhubchak OV, Vasenda MM. Dosvid stvorennia kombinovanykh preparativ na osnovi tiotriazolinu [Experience of combined drugs based on Thiotriazolin]. Proceedings of the 7th National Congress of Pharmacists of Ukraine Pharmacy of Ukraine: Looking to the future 2010;1: 469. Ukrainian.

4. Kucherenko LI, Borsuk SO, Belenichev IF. Pat. № a201604961, Ukraine. Combined anxiolytic, stress-protective, nootropic, antioxidant drug. - Zayavl. 04.05.2016; opubl. 24.06.16, Byul. № 12. Ukrainian.

5. Mazur IA, Belenichev IF, Kucherenko LI. [Study of the pharmacological properties of the new combined trypto-

phan with tiotriazoline (Report 1)]. Retsept. 2016;6: 697703. Ukrainian.

6. Kucherenko LI, Mazur IA, Borsuk SO. [Selection of excipients for L-triptophane tablets with thiotriazoline by wet granulation (Report 1)]. Farmatsevt chasop. 2017;3; 31-8. Ukrainian.

7. Bidnenko OS, Kucherenko LI, Mazur IA, Moryak ZB. [Choice of rational excipients to create "Angiolin" tablets by wet franualtion]. Farmatsevt chasop. 2016;2: 16-21. Ukrainian.

8. Hroshovyi TA, Martsenyuk VP, Kucherenko LI, Vronska LV, Huryeyeva CM. Mathematical planning of experiment in pharmacy. [Математичне планування експерименту при проведенні наукових досліджень в фрармації] Ternopil: TSMU; 2008. Ukrainian.

9. State Pharmacopoeia of Ukraine. 1 vol. [Державна Фармакопея України : в 3 т.] Kharkiv: State Enterprise Ukrainian Scientific Pharmacopoeial Center of Medicines Quality; 2015. Ukrainian.

Отримано 13.10.2017 